\title{
Highland malaria at the Kiziba UNHCR refugee camps ( 1950 m. a. s.)
}

\section{K. Molnarova1,2, S. Wolf', M. Tenna1,2}

\section{Original Articles}

${ }^{1}$ St. Elizabeth University St. Clementine Tropical program Bigugu, Rwanda

${ }^{2}$ UNHCR Rwanda Branch Kiziba, Rwanda

\section{Correspondence to:}

St. Elizabeth University, MSc and PhD Program, Dept. of Public Health, Nám. 1. Mája č. 1, 81000 Bratislava, Slovakia

Mary Immaculata SEU Tropic Program, Nairobi, Kenya

Submitted: 10.6 .2016

Revised: 18.8 .2016

Accepted: 12.9.2016

\section{Reviewers:}

W. Namulanda

Catholic university of Eastern Africa, Nairobi, Kenya

V. Okoth

Adjunct Lecturer Catholic University of Eastern Africa, Nairobi, Kenya

\section{Key words:}

Highland malaria.

\section{Key message:}

High CRP correlates highlands malaria.

CSWHI 2016; 7(3): 19-24; DOI 10.22359/cswhi_7_3_05 @ 2016 Clinical Social Work and Health Intervention

\section{Abstract:}

Introduction: Risk factors for highland malaria and difference diagnosis of highland malaria is discussed and analyzed in UNHCR refugee camps in Kizba, Rwanda.

Patients and Methods: Diagnosis of highland malaria was performed clinically plus microscopically (blood smear) and with rapid diagnostic test (RDT).

Results: 371 patients from an area of 4,777 residents were diagnosed for malaria and the mean levels of CRP where $70.1 \mathrm{~g} / 1$.

Conclusion: Despite Highland malaria at an attitude of 1,950 m.a.s. is very rare, CRP response in a patient was significant. 


\section{Introduction}

Highland malaria has after a subclinical, clinical course and sub-microscopical laboratory presentation chronic mild symptomatology, therefore is difficult to diagnose and only a few patients receive appropriate therapy (1-3). Chronic diseases with liver involvement especially in $\mathrm{P}$. vivax malaria is not uncommon even at a height of 2,000 m.a.s. (48). C-reactive protein is usually elevated but slides remain negative; rapid tests (RTD) and PCR are however positive (9-12). The aim of this research was to assess diagnosis treatment and burden of the disease (occurrence) of highlight malaria in UNHCR refugee population of a Rwandan refugee camp.

\section{Patients and Methods:}

We were using data from HMIS which is a surveillance document for monthly reporting unified by Rwandan Ministry of Health, which all healthcare facilities in the country are obliged to provide at the end of month and which is created by calculation of the nurse who occasionally undergoes trainings on how to collect data. In our Health Center in Bigugu this job was done by one person and afterwards it was rechecked by another employee of ours in order to ensure the reliability of our data. In the remaining two health facilities, where we couldn't ensure this double check, we also checked the accuracy of those reports by comparing data from books held by expert laboratory technicians, who are obliged to register every malaria positive case. In all health centers of our interest, laboratory technicians have attended on a regular basis attending training in order to improve their qualification.

Patients were examined for tropical malaria by microscopic examination using thick blood film stained by Giemsa in 95\% - 98\% of all malaria positive cases. In case of an absence of an expert laboratory technician or during the weekends, PhHRP2 based malaria rapid tests were used by a trained nurse. Tests were stored according to manufacturer's recommendation at $25^{\circ} \mathrm{C}$, protected from sunlight and humidity and no test was used after its expiratory date. In two out of three health centers, where use of a mosquito net is the gold standard, we also collected data regarding mosquito net distribution. We used Pearson's correlative coefficient in order to determine correlation between the prevalence of malaria in the Kiziba Health Center and Kibuye Health Center.

\section{Results: Description of the catchment area}

The longitudinal prospective quantitative study that began in February 2013 and ended in July 2015 was conducted at the Bigugu Health Center. BHC is a health facility which is located at the Rwankuba Sector, Karongi district, Western Province of Rwanda. The area of the study is localized at the altitude of 2,250 meters above sea level and belongs to an area with very low or no malaria transmission areas at all. Bigugu Health Center is a healthcare facility for the total population of 17,000 inhabitants. The majority of this population $(93 \%)$ as simple peasants earn their living by cultivating in their tiny field staple crops like beans, maize and potatoes. Due to their daily activities as well as the poor quality of their housing, they are constantly exposed to the mosquito bites, relying mainly on the fact that this area used to be too cold and unsuitable for breeding of mosquitos. 371 patients of varying age (8 months - 77 years) with suspected malaria over this period were examined also for the level of CRP.

Patients with typical presentation of other infectious diseases than malaria itself that can alter CRP (cough, symptoms of urinary respiratory infections or symptoms of gastroenteritis) were excluded from the study, as well as those who had in their medical 
histories travelled in the area of a lower altitude in the previous 30 days, as well as patients on steroids or other immunosuppressants. Only patients presenting with headache accompanied with elevated body temperature or history of fever in the previous three days as well as abdominal pain without diarrhea in child patients were included. Those patients were examined for tropical malaria by microscopic examination and occasionally (in 47 out of a total of 371 patients) double checked by PhHRP2 based malaria rapid tests. 371 cases suffering from highland malaria were also examined for CRP using the NycoCard Reader II Machine. All CRP tests were stored in the refrigerator according to the instructions of a manufacturer and no test was used after the expiratory date. All samples collected over the time were examined by the same person, an expert laboratory technician at the Bigugu Health Post. Retrospective quantitative study collecting and comparing data from January 2012 - July 2015 was performed at three health centers at the Karongi District of Western Rwanda.

Bigugu Health Center, Kiziba Health Center and Kibuye Health Center, which are localized at different altitude (2,250 asl, 1,950 asl and 1,450 asl retrospectively) cover a catchment area for a population comparable in size (17,000 in Bigugu, 19,500 in Kiziba and 24,000 at the Kibuye Health Center). The difference in the size of the population wasn't important for our research as we compared the number of malaria positive cases against the total number of OPD patients; calculating the prevalence of malaria out of it. While in the BHC catchment area the majority of the population do work as peasants (93\%), in the $\mathrm{KzHC}$ catchment area most of the population consists of refugees. The majority of the refugee population do not have any job and migrate a lot to the lower $\mathrm{KbHC}$ area in order to trade their food for other needed goods, though it is uncommon to spend the night there. In the $\mathrm{KbHC}$ area many people work in the third sector though unfortunately exact numbers are not available. For those people it is much more common to travel by bus towards the direction of the capital Kigali where malaria is more prevalent.

\section{Secondary Data and Document Review}

This method involved studying the varying and relevant written and published studies on issues of climate variability and impacts on malaria, vulnerability and adaptation of communities. It consists of data and any information obtained from other sources to act as a back-up on what has been found in the field. Secondary data help in supporting an argument since it offers justifications for the choice of topic. We reviewed all available articles written in English language on topic of either climatic change in Rwanda or climatic change and its effect upon malaria transmission in Rwanda which were published since 2004.

\section{Data analysis}

A) After collecting the data, we determined the mean level of CRP for each year separately, as well as the mean CRP in total. We determined the mean CRP level as a proportion of the sum of all CRP values to the number of all measured patients. In total, among 371 investigated malaria positive patients had an average CRP value of 70.6. 34 cases had a CRP level in values between 8 -25 mg/l; 79 cases in values between 25$50 \mathrm{mg} / \mathrm{l} ; 88$ cases in values between $50-75$ $\mathrm{mg} / \mathrm{l} ; 77$ cases in values between $75-100$ $\mathrm{mg} / \mathrm{l} ; 36$ cases in values between 100-125 $\mathrm{mg} / \mathrm{l} ; 27$ cases in values between 125-150 $\mathrm{mg} / \mathrm{l} ; 20$ cases in values between 150-175 $\mathrm{mg} / \mathrm{l} ; 10$ cases in values between 175 -200 $\mathrm{mg} / \mathrm{l}$. Out of 371 malaria positive patients no one had a CRP level higher than $200 \mathrm{mg} / \mathrm{l}$. 
The distribution of CRP levels in malaria positive patients admitted to the Bigugu Health Center in period 12/13-07/15. The mean CRP levels in patients suffering from highland malaria were analyzed separately each month. In those patients where malaria was confirmed not only by microscopy but also by using RAPIDs, out of 47, 44 were positive and 4 results were invalid but we did not repeatedly perform the examination in order to avoid unnecessary unpleasant procedures.

B) We calculated the prevalence over the time separately for each month. The prevalence was calculated for each health center as the number of malaria positive cases divided by the total number of patients attending OPD. Results were put into graphs, from which the following is obvious: The prevalence in each investigated health center increased multifold. The higher the altitude of the health center, the more significant the increase of malaria was observed. Regarding mosquito net distribution, while for Kiziba HC Pearson's correlative coefficient was negative -0 00541; at Kibuye HC Pearson's correlative coefficient was 0,11237 ; which means a positive correlation between number of distributed mosquito nets and number of malaria positive cases.

\section{Discussion}

The results of our study show that in the patients suffering from highland malaria the levels of CRP are significantly elevated, however, more voluminous studies of this topic are required as our study was limited by relatively small sample (1-3). We also suspect that in people repeatedly suffering from the attack of malaria (non-highland malaria) the values of CRP won't be so high as the response from the partially adjusted immune system isn't expected to be so aggressive. We also noticed that the value of CRP values even in BHC during last three years is slightly decreasing what is also in accord with our theory and it could be very interesting topic for an another research (4-8). As in the second part, our results point at that malaria is on the rise and in case of the malaria outbreak in Rwanda, people living in the highlands are more endangered. The increase of prevalence is more prominent the higher altitude. The explanation behind it might be a missing partial immunity against malaria. The explanation behind increased prevalence offered by the Rwandan Government is the low quality of donated mosquito nets or deficient impregnation on them (9-12).

\section{Conclusions}

Results of this study do prove that highland malaria has strong positive correlation with elevated value of C-Reactive Protein. Data from three health facilities in western Rwanda are all pointing out that malaria in this country is on the rise and this upsurge in malaria is even more significant than statistical data released by the Rwandan Government suggests. Also the review of the multiple documents researching the climate change in Rwanda are in accord, suggesting that global warming contributes just very little or not at all to this enormously increased incidence of malaria in the Karongi District in Western Rwanda. Necessary precautions like mosquito nets distributed to all people independently of the altitude they live at should be undertaken to stop this malaria spreading in Rwanda.

We reviewed seven relevant articles which were researching any connection between climatic change and rising malaria incidence. Though some authors very vaguely suggested that 'The results of this study indicate that future climate might become more suitable for malaria transmission in the tropical highland regions.' However, adding cautiously that other important socioeconomic factors such as land use change; population growth; urbanization; migration changes; economic development will have to be accounted for in further details for future risk 
assessments without any attempt to quantify their findings, most authors were in accord, that it should be recognized that changes in malaria are unlikely to be a major contributor to modifications in the total burden of disease owing to global climate change [42].

However, most important for our research is without any doubt an article saying:

A physically nearly unchanged regional climate zone is the area along Lake Kivu. The already-mentioned local climate peculiarity arising from the prevailing land-lake-wind circulation continues to cause climatic conditions that remain roughly the same, with slightly rising temperatures $(+0.5 \mathrm{~K})$ and a decrease in rainfall of around $50 \mathrm{~mm}$. While the area in southern Rwanda, especially around the Nyungwe Rainforest, exhibits modest temperature changes $(+0.5 \mathrm{~K})$ and continues to register rainfall totals of $>1,400 \mathrm{~mm}$, around the Virunga Volcanos the temperatures range about $2 \mathrm{~K}$ higher while total rainfall has clearly dropped (-250 $\mathrm{mm})$ [18].

This basically says that there was no climate change in the area of our interest as both Lake Kibu and Nyungwe Forests work as kind of buffers. In other words, whatever went wrong in the fight against malaria in Rwanda, to blame global warming for it is just an alibi.

\section{References}

1. MUPFASONI D, KARIBUSHI B, KOUKOUNARI A, RUBERANZIZA E, KABERUKA $\mathrm{T}$ et al.: Polyparasite Helminth Infections and Their Association to Anemia and Undernutrition in Northern Rwanda. PLoS Negl Trop Dis 3(9): e517, 2009

2. HRUZIK $\mathrm{J}$ et al: Infektológia, OSVETA, 1984, pp 355

3. RAJČÁNI J, ČIAMPOR F: Medical Virology, VEDA, 2006, pp 420

4. HRUBIŠKO M.: Rationale of therapy of Respiratory tract infections. Ambulantná terapia, 2/2007, $133 \mathrm{pp}$.
5. DJAČENKO SS, SINJAK KM, DJAČENKO NS: Pathogenic human viruses. AVICENUM, Praha 1980,

6. World Health Organization: World Malaria Report 2015, ISBN 978924156515 8, 2015

7. THE GLOBAL FUND, Results Report 2015, ISBN 978929224435 4, 2015

8. BEDNÁŘ M, a kol.: Lékařská mikrobiologie, MARVIL, 1996

9. BELL1 D R: Lectures notes on Tropical Medicine, Fourth edition, 1995

10. President's Malaria Initiative: Malaria Operational Plan, Rwanda FY 2015,

11. President's Malaria Initiative: Malaria Operational Plan, Rwanda FY 2013,

12. WORLD HEALTH ORGANIZATION: World malaria report 2014, ISBN 978 9241564830,2014

13. CHAVES LF \& KOENRAADT CJM: Climate change and highland malaria: fresh air for a hot debate. The Quarterly review of biology, 85 (1), 27-55. , 2010

14. HIMEIDAN YE, KWEKA EJ: Malaria in East African highlands during the past 30 years: impact of environmental changes, Front Physiol. Aug 2;3:315, 2012

15. AASE A, HABARUGABA G: Malaria invading the highlands of Africa: Global warming or local environmental change? Acta Geographica - Trondheim. Series B.No.11., 2006

16. ABUDA C: An Assessment of the impact of climate variability on malaria in Uganda., Master Thesis, Department of Geography, Norwegian University of Science and Technology, Tronheim, Norway, 2012

17. LINDSAY SW, MARTENS WJ: Malaria in the African highlands: past, present and future, Bull World Health Organ. 76(1):3345., 1998

18. HENNINGER SM: Local climate changes and the spread of malaria in Rwanda, Health, Vol.5 No.4, 2013

19. LOEVINSOHN ME: Climatic warming and increased malaria incidence in Rwanda Lancet, Mar 19;343(8899):714-8., 1994 
20. KAPPAS M: Klimatologie. Klimaforschung im 21. Jahrhundert: Herausforderung für Naturund Sozialwissenschaften. Spektrum Akademischer Verlag, Heidelberg, 2009

21. COENE J: Malaria in urban and rural Kinshasa: The entomological input. Medical and Veterinary Entomology, 7, 127-137, 1993

22. SIEBERTZ K, van Bebber D, Hochkirchen T: Statistische versuchsplanung. Springer Verlag, Berlin, 2010

23. UNITED NATIONS General Assembly. International Development Strategy for the Second United Nations Development Decade, paragraph 43. UN, 1970

24. MILLER JM., KORENROMP EL, NAHLEN BL, Steketee R: Estimating the number of insecticide-treated nets required by African households to reach continent-wide malaria coverage targets, Journal of the American Medical Association 297 (20): 2241-50, 2007

25. NOOR AM, MUTHEU JJ, TATEM AJ, HAY SI, SNOW RW: Insecticide-treated net coverage in Africa: Mapping progress in 2000-07 Lancet 373 (9657): 58-67, 2009

26. UNICEF, WHO: Achieving the malaria MDG target: reversing the incidence of malaria 2000-2015, ISBN 978924150944 2, 2015

27. SCHLAGENHAUF-LAWLOR P: Travelers' Malaria, p. 215, BC Decker Inc, Hamilton, Ontario, 2008

28. WORLD HEALTH ORGANIZATION: Instructions for treatment and use of insecticide-treated mosquito net, p. 34, 2002

29. ENAYATI A, HEMINGWAY J: Malaria management: Past, present, and future". Annual Review of Entomology 55: 569-91, 2010

30. WORLD HEALTH ORGANIZATION: World Malaria Report 2014, ISBN 978924156483 0, 2014

31. WORLD HEALTH ORGANIZATION: WHO Position Statement, Indoor Residual Spraying: Use of Indoor Residual Spraying for Scaling Up Global Malaria Control and Elimination, 2006

32. VAN DEN BERG H: Global status of DDT and its alternatives for use in vector control to prevent disease, Environmental Health Perspectives 117 (11): 1656-63, 2009

33. PATES H, CURTIS C: Mosquito behaviour and vector control, Annual Review of Entomology 50: 53-70, 2005

34. TUSTING LS, THWING J, SINCLAIR D, FILLINGER U, GIMNIG J, BONNER KE, BOTTOMLEY C, LINDSAY SW: Mosquito larval source management for controlling malaria, Cochrane Database of Systematic Reviews 8: CD008923, 2013

35. LALLOO DG, OLUKOYA P, OLLIARO P: Malaria in adolescence: Burden of disease, consequences, and opportunities for intervention, Lancet Infectious Diseases 6 (12): 780-93, 2006

36. LAWSON JB, HARRISON KA, STAFFAN BERGSTROM S: Maternity care in developing countries, chapter Malaria in pregnancy, RCOG Press, 2001

37. WICZMANDYOVA D, MURGOVA A, The life of diabetics, life with diabetes, Book Clear Michalovce ISBN 978-809711629255.2012, pp 67

38. THE REPUBLIC of RWANDA, MINISTRY of HEALTH: Rwanda Annual Health Statistics Booklet 2014

39. BARTOLONI A, ZAMMARCHI L: Clinical aspects of uncomplicated and severe malaria, Mediterranean Journal of Hematology and Infectious Diseases 4 (1): e2012026, 2012

40. WALKER BR, COLLEDGE NR, RALTSON SH: Davidson's Principles and Practice of Medicine, 21st edition, p 351, 2010

41. WARHURST DC, WILLIAMS JE: Laboratory diagnosis of malaria, J Clin Pathol 49 (7): 533-38, 1996

42. SILHAROVA B, SUVADA J, FRANEKOVA M, NOGE A, MIKOLASOVA G: Malaria in hyperendemic region, Neuroendocrinology Letters. 34, 2013, s1 38-43 